\title{
Forty Years of Political Science in Europe: The European Consortium for Political Research Celebrates Its Ruby Anniversary
}

Luciano Bardi, University of Pisa and Chairman of the ECPR

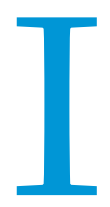

n 2010, the European Consortium for Political Research (ECPR) celebrated its fortieth anniversary as the leading association for political science in Europe. Forty-one years earlier, in 1969, three European political scientists sent a letter to about a dozen of their European colleagues outlining some suggestions for creating an informal network of institutions and centers interested in comparative politics research. The authors of the letter were Serge Hurtig, Jean Blondel, and Stein Rokkan. Over the next year, led by Blondel and Rokkan with the support of a number of leading professors at the forefront of comparative research in their respective countries (the "founders" being Serge Hurtig, Norman Chester, Hans Daalder, Richard Rose, Jorgen Westerstahl, and Rudolf Wildenmann) and the backing of the Ford Foundation, the ECPR began to take shape. The original plan called for a European journal, a summer school, inventories of European political scientists and graduate courses, workshops, a data information center, and the construction of a transnational infrastructure of institutions to foster a selfsustaining community of professional political scientists. On July 29, 1970, a Ford Foundation grant was awarded to support the achievement of these aims, and the ECPR was established.

In the forty years since this group of professors held their first meeting, the ECPR has grown into a leading force in political

Jean Blondel, one of the ECPR's founders, enjoys a reception to celebrate the ECPR's 4oth anniversary during the Joint Sessions in Münster.

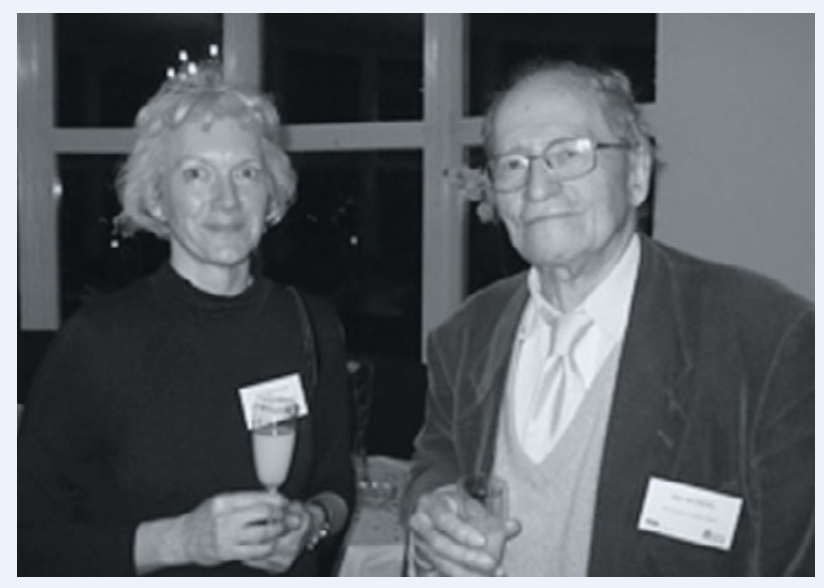

science. The first Joint Sessions of Workshops were held in Mannheim in 1973; now the ECPR's flagship event, this event attracts some 600 participants each year and has produced a book series published by Routledge entitled Studies in European Political Science. Later, in 1973, the first issue of the European Journal of Political Research (EJPR) was published, edited by Arend Lijphart. Now, nearly 40 years later, the EJPR continues to be ranked as one of the leading journals in European political science.

\section{INTERNATIONAL MEMBERSHIP AND WORLD-CLASS EVENTS}

Membership of the ECPR now stands at over 350 institutional members worldwide, and this number continues to grow alongside the scope of the ECPR's activities. In the past 10 years alone, the ECPR has added to its annual calendar a General Conference (held biennially in the autumn), which now attracts around 2,500 international participants, and, alternating each year, a Graduate Conference that attracts around 600 students from across the world. In addition to these events, an annual Summer School in Methods and Techniques was established in 2006, held at the University of Ljubljana, and a Capital Lecture Series was launched in 2008 in Madrid, followed by a London iteration in 2009, and with the next scheduled for Rome in 2011. In 2011, the ECPR will also relaunch one of its earliest initiatives, the Research Sessions, at the European University Institute in Florence.

\section{ECPR staff show off commemorative scarves and the 4oth anniversary book at the Joint Sessions in Münster.}

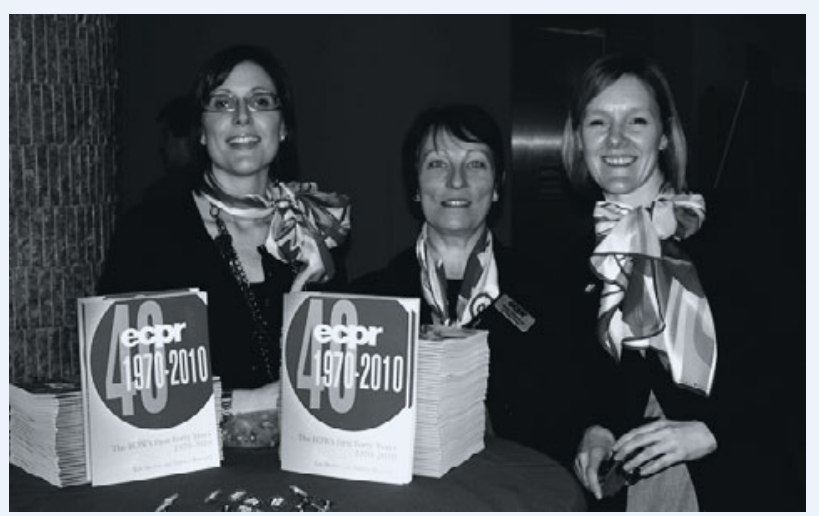




\section{Long before e-mail .... the ECPR's first communication to its membership, October 1970.}

\section{EUROPEAN CONSORTIUM FOR POLITICAL RESEARCH}

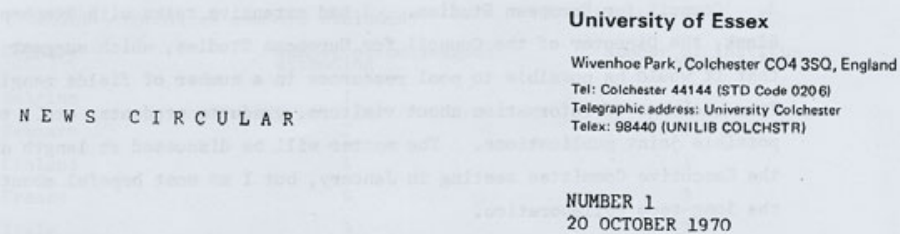

This news circular will be sent regularly to members of the European Consortium for Political Research and in the first instance every two months (except during the summer). Because of Christmas the next issue will be on December 10th: would you please let me have any items which you want to see included by December 1st.

The format will obviously change from time to time but I hope to keep the headings broadly similar to the present ones.

I GENERAL MATTERS AND LINKS WITH OUTSIDE BODIES

1. The Ford Foundation has now finally given its approval to the grant for the European Consortium for Political Research.

2. I saw Peter de Janosi on October 14th. We had a comprehensive survey of all the activities of the ECPR and I was under the impression that he was very pleased about the way things had started. He will try to appear in Colchester after the Executive Committee meeting on the 15th of January.

Executive Director: Profester 1 810ndes

Executive Committee: Professor Stein Rokkan (Bergen) (Chairmsn), Mr D.N. Chester (Nutfield Collegel), Professor Hans Dasider (Levden) Mrs. Hurrig (Institut d'Etudes Politiques, Paris), Professor Anthony King (Essex), Professor Richard Rose (Strathelyde), Professor Jorgen Westerstähl (Göteborg), Profeswor Rudolf Wildenmann (Mannheim)

A GROWING PUBLISHING PORTFOLIO AND ITS OWN PRESS

Building on the success of the EJPR, the ECPR's publishing portfolio has also seen continued growth over the last 40 years, creating a number of high-profile and prestigious places to publish research: the Comparative Politics book series, published by Oxford University Press, was established in 1990, followed by the Studies in European Political Science series, published with Routledge, in 1994, and the new Research Methods series, published by Palgrave Macmillan, in 2008. As the EJPR has gone from strength to strength since 1973, the ECPR added a professional journal, European Political Science (EPS), published by Palgrave Macmillan, in 2001, and a new, general journal, the European Political Science Review (EPSR), published by Cambridge University Press, in 2009. In 2006, the ECPR even launched its own publishing imprint, the ECPR Press. Based at the ECPR's Central Services at the University of Essex, the Press publishes cutting-edge research in political science alongside reissued classics such as Giovanni Sartori's Parties and Party Systems and has quickly become known as a successful small publisher with a solid reputation.

\section{FACILITATING MOBILITY AND MARKING} ACHIEVEMENT

In addition to its events and publications, the ECPR's key concerns are networking the political science community (through its Standing Groups), providing funding for conference attendance (through the Travel and Accommodation Grant and Scholarship), and acknowledging achievement in the discipline (through prizes such as the Jean Blondel Ph.D. Prize or the Lifetime Achievement Award).

\section{CELEBRATING THE ANNIVERSARY}

2010 saw a number of events and activities to mark and celebrate the fortieth anniversary of the ECPR, including special publications, panels, roundtables, receptions, and even commemorative scarves, ties, and other memorabilia. Most activities were coordinated around the ECPR's key annual event, the Joint Sessions of Workshops, held in Muenster in 2010, but events continued throughout the birthday year.

\section{SPECIAL PUBLICATIONS}

The key events and milestones of the first 40 years of the ECPR have been brought together with firsthand recollections of those events in a book entitled The ECPR's First Forty Years by Ken Newton and Thibaud Boncourt (ECPR Press, 2010). Alongside this publication, a special "Ruby Red" supplementary issue of EPS on "Forty Years of European Political Science" was published in late 2010, also marking the anniversary.

\section{INTERNATIONAL PARTICIPATION}

Throughout its lifetime, the ECPR has striven to develop links between its international and regional counterparts. In recent years, this collaboration has taken the form of holding panels at the annual meetings of sister organizations, hosting receptions, and exhibiting in book exhibitions. These events are key to the ECPR's outreach strategy and the furtherance of its goal of bringing political scientists together. In 2010, the ECPR organized panels at the U.K. Political Studies Association's annual conference in Edinburgh; the International Studies Association's annual meeting in New Orleans; and the APSA's annual meeting in Washington, DC. More importantly, 2011 will see the ECPR organize its first joint conference outside of Europe as it stages the International Political Science Association (IPSA)-ECPR Conference in Sao Paulo, Brazil, in February. This event will be another key milestone in the ECPR's continued growth.

\section{LOOKING AHEAD: ANOTHER FORTY YEARS}

If 2010 was a busy year for the ECPR, then 2011 promises to be even more so, with a full calendar of events that will range throughout Europe and beyond, to locales including Rome, St. Gallen, Sao Paulo, Ljubljana, Reykjavik, and San Francisco. Never one to rest on its laurels, the ECPR is constantly moving forward, but always with its original aims and the needs of its membership 
and the profession at its heart. 2011 is the tenth anniversary of the ECPR's professional journal, EPS, and 2013 will be the fortieth anniversary of the EJPR. New initiatives are always under development, such as constant improvement of the functionality of the ECPR website to make it a hub for political scientists throughout the world. The ECPR's ambition is to be a genuinely global force, and for this reason, amendments were made to its Constitution in this anniversary year to allow non-European members, who previously had to be content with Associate Member status, to become full members with voting rights and all the benefits that full members currently enjoy. The ECPR looks forward to welcoming new non-European members to help it achieve its goals. 


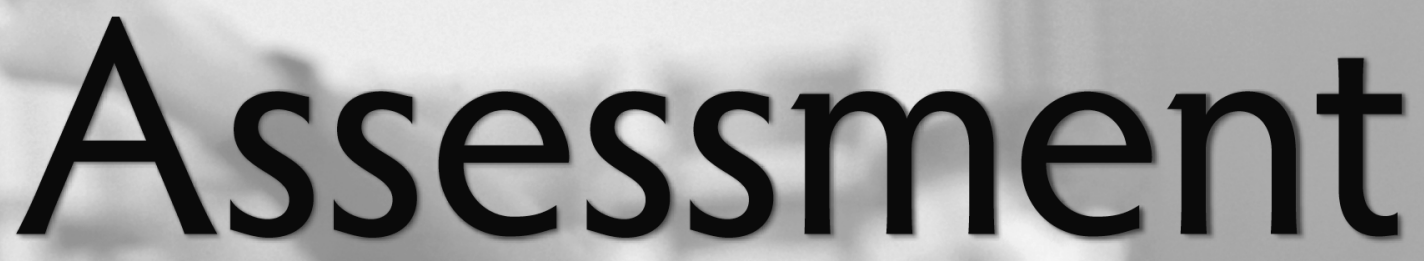
in Political Science

7
5
0
5
3
0
5
7
5

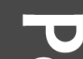

O

롤. Michelle D. Deardorff

ก

(0) Kerstin Hamann

u John Ishiyama

อุด

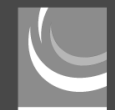

editors

apsa

AMERICAN POLITICAL SCIENCE ASSOCIATION STATE OF THE PROFESSION SERIES

Order online at www.apsanet.org/pubs 